\title{
Institutional routines and interpersonal conflicts among elderly in a Long-Term Care Facility*
}

\author{
Rotinas institucionais e ocorrência de conflitos interpessoais \\ entre idosas em instituição de longa permanência \\ Rutinas institucionales y ocurrencia de conflictos interpersonales \\ entre ancianas en establecimiento de larga estadía
}

How to cite this article:

Bruinsma JL, Beuter M, Borges ZN, Jacobi CS, Benetti ERR, Backes C. Institutional routines and interpersonal conflicts among elderly in a Long-Term Care Facility. Rev Esc Enferm USP. 2021;55:e20200560. DOI: https://doi.org/10.1590/1980-220X-REEUSP-2020-0560.

\section{Jamile Lais Bruinsma ${ }^{1}$ \\ Margrid Beuter ${ }^{1}$ \\ Zulmira Newlands Borges ${ }^{1}$ \\ Caren da Silva Jacobi ${ }^{1}$ \\ Eliane Raquel Rieth Benetti ${ }^{1}$ \\ Carolina Backes ${ }^{1}$}

* Extracted from the thesis: "Conflitos interpessoais de idosas em uma instituição de longa permanência: estudo etnográfico", Universidade Federal

de Santa Maria, 2020.

${ }^{1}$ Universidade Federal de Santa Maria, Santa Maria, RS, Brazil.

\begin{abstract}
Objective: To describe the influence of institutional routines on interpersonal conflicts among institutionalized elderly women. Method: A qualitative study, with an ethnographic framework, performed with 17 elderly women in a Long-Term Care Facility. The field immersion occurred from August 2017 to May 2018. The data were produced by participant observation and fieldnotes and analyzed through the sociocultural perspective with theoretical tools related to the total institutions described by Erving Goffman. Results: External bonds outside the institution and the routines were trigger factors of conflicts in the Long-Term Care Facility. The dissatisfaction with the lack of external bonds was noticed in the impossibility of leaving with family members, receiving visits, objects, money, foods, or attention. The standardization and collectivization of internal routines of basic activities generated dissatisfaction and challenged the elderly women's tolerance towards the norms. Such situations facilitated interpersonal conflicts in the institutional environment. Conclusion: The conflicts occurred among elderly women and professionals, and among them, from the insubordination of the elderly, based on the idea of reaffirming their individualities.
\end{abstract}

\section{DESCRIPTORS}

Conflict, Psychological; Aged; Homes for the Aged; Geriatric Nursing; Anthropology, Cultural.
Corresponding author:

Jamile Lais Bruinsma

Av. Juscelino Kubitschek de

Oliveira, 4808, São Gonçalo

96080-780 - Pelotas, RS, Brazil

jamilebruinsma@hotmail.com
Received: $12 / 23 / 2020$

Approved: 05/21/2021 


\section{INTRODUCTION}

Demographic transition due to population ageing has been occurring rapidly, which constitutes a challenge, particularly for developing countries. This context demands the structuring of social and public health services, which must organize practices and services to meet the recurring demands of senescence and the increase of age-related chronic diseases ${ }^{(1)}$.

Care directed at the elderly, traditionally offered by family members, are currently undergoing a reorganizing process, resulting from changes in family structure. Due to divorce and prolonged widowhood, the number of elderly living alone is increasing ${ }^{(2)}$. Moreover, historical, sociocultural, political, and financial aspects impact elderly familial arrangements and the family's role as a care provider ${ }^{(2)}$. In this context, the number of elderly people living in the Long-Term Care Facility (LTCF) is also increasing.

The LTCF are collective residencies designated for assisting elderly with different degrees of dependence, in a situation of economic vulnerability or requiring longterm $\operatorname{care}^{(3)}$. The vulnerability situations which lead to institutionalization are diverse; among them, not having a partner or children stands out ${ }^{(4)}$. In addition, cognitive impairment and functional dependence for the basic activities of daily living ${ }^{(4)}$ result in the need for specific care and social support, which mostly cannot be provided by the family at home.

The LTCF are usually closed spaces whose daily functioning is determined by standardized routines and rules which prevent individual manifestation and are thus characterized as "total institutions". These institutions provoke a series of "profanations of the self" which afflict, even though unintentionally, the "mortification of the self” (5). Repercussions of this situation can be perceived in conditioning the elderly to norms and routines, which include discipline for the time to sleep and eat, making them distance themselves from personal objects and limiting individual spaces ${ }^{(6)}$.

Institutionalization impacts the elderly's previously established familial and social relations, with the possibility of breaking or weakening bonds. Besides, when institutionalized, the elderly undergo a resistance and denial process and need to adjust to this new reality. With time signs of wear and tear appear, represented by disturbing situations in interpersonal relationships, which frequently lead to conflicts ${ }^{(7)}$.

Interpersonal conflicts occur in living with people or groups which experience disagreements, incompatible opinions or opposed interests ${ }^{(8)}$. Upon this not necessarily physical clash, suffering, distress, or negative emotions may arise. On the other hand, conflict may become positive when leading to problem resolution, facilitating the fulfillment of the individual needs ${ }^{(9)}$.

Interpersonal conflicts are present in the relationships between elderly women and the LTCF professionals, associated to the different circumstances present in the institutional everyday life, such disputes for affection, personal objects, and physical spaces ${ }^{(10)}$. By reason of that, understanding the occurrence of conflicts under the perspective of the institutionalized elderly women submitted to the norms and routines which possibly produce effects in the everyday life and in the relations which structure this context is remarkably important. Understanding the conflicts in this environment may guide the health professionals' actions with the objective of promoting coping strategies for this type of situation and mitigating their impacts on the relations, on socialization and on the health of the institutionalized elderly.

Given the above, this article poses the question: What is the influence of institutional routines on the occurrence of conflicts among elderly women in a Long-Term Care Facility? In order to answer it, this study aimed at describing the influence of institutional routines on the occurrence of interpersonal conflicts among institutionalized elderly women.

\section{METHOD}

\section{Type Of Study}

A qualitative ethnographic study.

\section{SCEnARIO}

The study was conducted in a long-term care facility which welcomes and shelters elderly women, located in the central region of Rio Grande do Sul state. In this institution a previous study on the existence of conflicts among the resident elderly women was conducted ${ }^{(10)}$, in which the need to further discuss the theme was noticed. The institution is structured into four wards sheltering circa 160 elderly women.

\section{Population}

The interlocutors were defined during ethnography based on interactions with the elderly women and their narratives, ideas, and experiences. A dialogical relationship was structured between the researcher and the LTCF elderly and some of them were perceived to have experienced situations with a conflict potential, making them interlocutors in this study. The interaction and proximity between elderly women and researcher occurred during participation in LTCF routines: meals, body hygiene, chimarrão (typical mate hot drink) circles, festivities, walks, and handicraft. The interlocutors were chosen considering their cognitive conditions, memory preservation and interaction, identified by the researcher throughout the visits to the study field. Thus, 17 institutionalized elderly interlocutors were chosen.

\section{Data Collection}

The data were collected through participant observation and fieldnotes. The field immersion period took place from August 2017 to May 2018. Participant observation was systematized based on the social relations of the institutionalized elderly women. The individual and collective physical spaces used by the elderly, the daily routines' organization, 
institutional and coexistence norms and reports or episodes of conflict involving the elderly women were observed.

The researcher visited the institution during the day from Monday to Friday. The mean duration of permanence of the main researcher at the place was four hours, amounting to 324 observation hours. The fieldnotes were elaborated from the oral reports and experience and observation description. The information was registered on paper concomitantly to observation and subsequently transcribed to a Word document. Data validation occurred by confirmation, i.e., in the recurrent individual encounters between researcher and interlocutor, the confirmation of what was previously heard, observed, and experienced was sought, taking into account the object of study. In order to ensure participants' anonymity, they were identified by pseudonyms.

\section{Data Analysis and Treatment}

Data registered into fieldnotes composed the empirical material to be analyzed. This research corpus was submitted to sociocultural analysis, with theorizations related to the Total Institutions described by Goffman ${ }^{(5)}$. The pathway between the field experience and the analytical interpretations was guided by the ethnographic method steps suggested by Fonseca ${ }^{(11)}$, which considers the subjects in their historical and social context. After data collection, the constituted bonds of the elderly in the institutionalization context were sought to be understood, with an emphasis on elements related to the attitudes and stances in situations which triggered conflict relations. Subsequently, the material was organized based on the similarity between discourses and issues manifested through the speeches and situation involving the interlocutors, specified by the dialogue excerpts and analyzed situations. Upon detecting regularities and seeking to stress patterns which permeate the multiple subjects and circumstances of a certain process, interpretations, values, and emotions can be achieved ${ }^{(11)}$. Also in this step, a bibliographical search was conducted, seeking for data on the institution and, through comparative lens, similarities and divergences between the experiences in this context were highlighted.

\section{Ethical Aspects}

This research was conducted in accordance with the norms of Resolution 466/2012 of the National Health Council $^{(12)}$, which deliberates on research involving human beings. It was approved by the Research Ethics Committee of Universidade Federal de Santa Maria, on opinion 2.170.510, July $12^{\text {th }}, 2017$. All participants were explained on the study objective and ethical precepts regarding voluntary and consented participation of each one were respected, as established in the Informed Consent Form.

\section{RESULTS}

The interlocutors were between 60 and 95 years old. Most of them came from the central region of the state of Rio Grande do Sul, did not have a partner and had an income of one minimum wage. Institutionalization time varied from one to 53 years. Most elderly women had chronic non-communicable diseases, especially cardiovascular diseases. Regarding type of dormitory, shared dormitories were predominant.

External bonds and the routines were trigger factors for conflicts within the LTCF. Among the external bonds maintained by the elderly, those with their children and siblings stood out. The interlocutors identified family and/ or friends as contact references, whose participation occurred in different ways, through telephone calls, weekly visits, or sporadic contact.

Lack of external bonds was determinant in the social relations of the elderly women and for conflict production. Those who had bonds within the institution, though somehow fragile, manifested their dissatisfaction regarding the impossibility of going out with family members, receiving visits, objects, money, foods, or attention.

The routines at the LTCF structured and organized activities such as eating, body hygiene, nursing care, and socialization, which were performed in preestablished moments, according to the nursing professionals' routine. In the morning, elderly women woke up and took their medicines at six and eight. The change of shift from the night nursing team to the morning one occurred at seven. The morning shift team divided their tasks into administering medications, helping with bathing and organizing the elderly women's breakfast.

Implicit rules were also observed to exist, towards which no formal regulation seemed to exist and in face of which the elderly women knew how to act, monitoring one another. An example happens when one loses their clothes upon the laundry delivery - a situation in which any piece of clothing could go to another elderly woman. Those who resisted the impositions and sought freedom movements were subjected to experience conflicts as response.

Around 18 p.m. the last daily meal was served and subsequently the elderly retired to their dormitories, either alone or helped by the nursing professionals. The routine was imposed so all of them would go early to their dormitories. This provoked dissatisfaction, especially during the summer, when the early time to sleep would become more evident.

Dinner is too early, now we have dinner and go to sleep, when the sun is still high. At the beginning, when I came here, I thought this was too strange, I passed hours lying down, waiting for the time to go by. Now I'm used to it (...) (Aurora, December 2017).

(...) Benedita reports that, sometimes, she wishes she could stay longer at the food court after dinner, but soon an employee appears asking her to go to her bedroom, because it is time to sleep. She reports that she goes to her bed, but cannot sleep. She used to watch $T V$ in her bedroom, she liked telenovelas and the news. However, the employee would soon come and ask to turn it off in order to avoid noise. So she asked her brother to take the TV. She then reports that the institution looks like a military headquarters, because at night the employees go to each room to check whether they are sleeping and since she cannot 
sleep so early, she closes her eyes and pretends (...) (Fieldnotes, January 2018).

Still on the context of institutional routines, garments like pajamas or nightgowns were not allowed in shared spaces, such as the living room during the day. However, some elderly women slept after lunch and then would opt for wearing them:

(...) When talking to an employee she would call an elderly woman's attention: "In pajamas already, Olga? I've told you before that you should not wear pajamas! It is just for sleeping." The elderly woman was with her pajamas blouse, had just woken up after lunch. I can tell it is a house rule, during the day one cannot wear pajamas, only for sleeping. During the afternoon some employees go through each dorm and leave the nightgown or pajamas on their beds so they can wear them at the end of the afternoon, before they go to sleep. But the elderly woman paid no attention to the comment, went to the living room and continued with her lilac pajama blouse (Fieldnotes, October 2017).

The norms and routines permeated the activities, including individual needs, such as eating. One of the norms was the collectivization of eating, performed inexorably in the food court and in moments preestablished by the institution. Even the menus and predefined schedules would prevent the elderly's individual preferences. This practice dissatisfied the elderly women, who would manifest their desires for other foods, such as different types of bread and cakes:

(...) "Lady! What's for teatime today?" So, I reply that it is cookies and tea. "Oh, so I don't want them. Every day it is either cookies or banana." (Fieldnotes, November 2017).

The elderly women with a social support network external to the institution received frequent visits from family and friends and were gifted with cookies, bread, cakes, jellies, and fruits. In these occasions, some elderly women also received financial support. This affected their autonomy to manage their own resources. They were allowed to keep foods in their dormitories and eat them whenever they wanted. However, not all of them had contact with visits which would facilitate their access to this type of food so they would be restricted to the LTCF menu, which enables to state that external food was not submitted to institutional rule. Such element was an indirect source of conflicts, since it stressed the inequalities among the residents.

Body hygiene occurred only in the morning shift, preventing the residents from choosing its moment and resulting in the crowding of both elderly and employees in the bathroom. The bathing routine was organized according to the level of dependence of the elderly. The independent or semi-independent elderly should wait for an employee to help them in the timely moment during the morning shift. Elderly who were independent for daily life activities reported waking up early so they could bathe, just like Simone who would wake between 4:10 and 4:30 a.m., avoiding lines and crowds:
(...) Simone tells me that her day begins really early, setting the alarm clock for between 4:10 and 4:30 a.m., she wakes up and showers. After that she lies down again (...) She justifies saying that she does that in order to have a calm bath. Afterwards the number of elderly women to have a shower is higher and the moment for bathing is only the morning shift, they are not allowed to do that another time. At times, after her shower she sleeps a little bit more, up to 6 a.m., when the nursing technicians bring their medicine (...) (Fieldnotes, January 2018).

There were some opportunities for the elderly women to experience other activities outside the LTCF, but only accompanied by an employee, volunteer, or family member. These outings were organized by the institution or by the invitation of family members or volunteers and included activities such as going to shopping malls, ice cream parlor, hairdresser, lunch with the family, among others. These activities were not frequent:

(...) Nice says that the institution is like a prison and that she wishes she could go out to take a walk, go downtown, but she cannot do that alone. When she got someone to take her, she was out of money, so she decided not to go. Now that she has the money, there is no one to take her, she will try to ask her sister, because her children live in other cities. She and Amábile talk, highlighting that they should not be there, that this institution is for old people and those who need help, which is not their case (...) (Fieldnotes, December 2017).

\section{DISCUSSION}

The imposed routines at the LTCF are similar to those described for total institutions ${ }^{(5)}$ : submission to institutional norms and control by authorities (professionals), including basic daily life activities, such as bathing, eating, and getting dressed. The standardization and collectivization of a daily routine generated dissatisfactions, challenged the elderly tolerance towards the norms and facilitated the occurrence of interpersonal conflicts in the institutional environment.

In face of the constant rules, routines and prohibitions of the LTCF, the elderly women reacted upon attempting to adapt to the context. Among the strategies were the "adaptation tactics" of the residents, which include the "situation distancing" - indifference towards the events; the "intransigent tactics" - denial to cooperate with the institution; the "colonization" - visualization of the institution as satisfactory, having as reference the external world; and the "conversion" - when the resident totally accepts her role as institutionalized ${ }^{(5)}$.

Regarding the routine of returning to their dormitories, the elderly woman reveals that, even with some estrangement, she needed to adjust to the established condition, using "conversion" ${ }^{(5)}$ as an adaptation tactic. This is a form of adaption to the institutional environment in relation to the constant processes of mortification: the elderly woman seems to accept the imposed condition, since it is the only option offered to her and try to represent the role of the perfect resident with an exceptional behavior. 
The institutional rules did not allow the elderly women to stay longer in the food court or in the living room after dinner. In order not to have problems with the professionals, the elderly woman sought to lie down at the established moment; however, she would challenge the rules by staying awake until she was sleepy. Such attitude provided a certain freedom of choice, considering the dormitory space and the absence of the professional. People not always reduce themselves to what the institution imposes, even when they do not actively resist ${ }^{(13)}$. When the elderly women defied the norms, they used the "intransigent tactics"(5). In this sense, small insubordinations are constant and test the limits of the institution's rules, in addition to guaranteeing to some elderly women the feeling of autonomy and preserved individuality upon persisting in their small desires, even if only temporarily.

The elderly's attitudes in disagreement with an institutional rule were verbally reprimanded by the employees. Thus, conducts such as keeping their pajamas, eating, watching television outside the preestablished hours and manifestations through gestures and annoyed facial expressions of showing the dissatisfaction with the situation, are resistance acts, of autonomy, for the "maintenance of the self". In this context, restrictions instituted on the choices of the daily routine contribute for the elderly women "mortification of the self" as it prevented their choice and annihilated their autonomy.

The eating routine is related to lifestyle maintenance or identity. Similarly to the studied institution, elderly evidenced that in Dutch facilities of long term care the moments of eating were predetermined by the institution, there were few options in terms of foods or places to seat. With little or no possibility to interfere in these situations, the residents lived with the feeling of limitation on how to live their lives the way they wanted ${ }^{(14)}$.

In response, some of them activated means of guaranteeing the "minimum demands for the construction of a life"(5). Those who had contact with family members and friends and had economic capital sought in them a "freedom movement", a possibility of restoring the "mortified self". And those who did not have that alternative would seek in conflicts a possibility of resisting to the annulation of the "self", keeping their individuality and personality, including their right to eat and choose the best moment to get dressed and perform their body hygiene.

The external social bonds are of great importance. According to a study conducted with institutionalized elderly, their feelings of autonomy were sustained in the relations with external persons, who, in addition to provide outings, would bring them goods and items, which the elderly considered necessary ${ }^{(15)}$. In this study, the elderly with more economic and social capital would have more privileges, such as staying in a private room or acquiring foods of their preference, whereas the others with less external contacts or less economic capital would be more subject to the "deterioration of the self" common in total institutions.

The health team plays an important role in the social life of institutionalized elderly, particularly when their relations with external persons are rare and there is little or no proximity between the residents ${ }^{(16)}$. However, nursing care was perceived to derive from standardized routines which would focus on fulfilling their basic health needs, such as helping with eating and body hygiene, administering medication and transferring the elderly among the rooms, leaving as secondary attention, listening, interaction and conflict resolution.

Body hygiene was identified to be influenced by the functional dependence levels of the elderly. The way they follow the routines is related to the dependence level of each elderly, and those with more autonomy can opt for the best moment to bathe or eat. Thus, the greater the dependence, the greater the subordination to the institution's interests ${ }^{(7)}$.

Routines are necessary for the good functioning and organization of a residence, just as in houses. However, when routines are strict and with little flexibility, they put the elderly's autonomy and the space occupied by them in the LTCF $^{(17)}$ at risk. The fact that the routines were defined by others is also a problem in the LTCF regarding the prevention of the "mutilations of the self", once the elderly had no power to change the routines by themselves.

Choosing the moment to bathe and the will to do it, choosing their clothes and opting for participating or not in the activities represent the minimum exercise of the "self" for institutionalized elderly ${ }^{(18)}$. The act of taking control of the activities constitutes an opportunity for them to perform self-care, obtain a more comfortable and dignified life in relation to the institutional restrictions and then feel alive by keeping their autonomy and preserving their independence, which impacts on a dignified ageing process with quality of life in the institutional context ${ }^{(19,20)}$.

Restrictions regarding outings were compared by the elderly women to prisons. They demonstrated the desire to socialize outside the institutional context, where they believed there would be people with the same functional capacity, differently from the other residents, who they considered "old people". Grouping residents as per their dependence or independence for daily life activities is a problem for the independent ones, as they live the dilemma between their social real surrounding and the desired one, which leads them to social isolation ${ }^{(16)}$.

This research's results enable to identify the existence of the "mortification of the self" derived from the routines established by the LTCF. Knowing this, measures to approximate the LTCF to a residential routine, completely different from a total institution's, could be taken.

The need to advance in relation to the health professionals' training, especially nursing, is emphasized, since they have an important role in LTCF. Including courses on gerontology and geriatrics in the technical and highlevel education may contribute to the qualification of these professionals.

The choice for the interlocutors with greater autonomy and independence is a limitation of this study as it does not include elderly with degrees of cognitive impairment or physical dependence. The fact that two wards, out of four 
in the institution, were not included in the immersion, as they were constituted by elderly with severe degree of physical or psychic dependence, do not exempt them from the "mortifiers of the self" routines and rules present in the other wards. Other studies on these groups are suggested in order to understand and describe the factors which influence and provoke conflicts in these LTCF environments.

\section{CONCLUSION}

Choices regarding individual needs, such as eating, getting dressed, the time to sleep and bathe, were preestablished and controlled by the LTCF. Conflicts occurred from the insubordinations of the elderly, sometimes subtly, based on the idea of reaffirming their individualities in a context of constant "mortification of the self".

The "Total Institutions" theory has enabled to comprehend the LTCF routines, characteristics such as norms and rules which institute activities and define barriers to the external world. In this context, the elderly women lived under recurrent tension in relation to the impositions and reacted with resistance movements, configuring conflicts.
In the LTCF, nursing care was identified to be directed at fulfilling basic health needs such as eating, hygiene, and medication administration, disregarding attention, listening, interaction, and conflict resolution. As a residential environment, the LTCF received elderly women with different habits, histories, personalities, and health conditions into a single environment; yet, it posed limiting rules for the care practice, hindering identity preservation and the autonomy of the elderly women. The institution, with its rules and hierarchies, creates the conditions which facilitate conflict, limiting nursing performance.

Institutional practices which inflict loss of identity and autonomy provoke opposed situations in relation to the care proposed by the institution. This study is expected to inform managers and health professionals who work at LTCF in order to enable the adjustment of routines to the interests and needs of institutionalized elderly, promoting the flexibilization of the basic activities schedule, such as bathing and eating; their freedom of movement, both in private and collective spaces; access to leisure activities; and the preservation of external bonds with family members, friends, and volunteers.

\section{RESUMO}

Objetivo: Descrever a influência das rotinas institucionais na ocorrência de conflitos interpessoais entre idosas institucionalizadas. Método: Estudo qualitativo, com enfoque etnográfico, realizado com 17 idosas de uma instituição de longa permanência. A imersão no campo ocorreu no período de agosto de 2017 a maio de 2018. Os dados foram produzidos por meio da observação participante e diário de campo e analisados sob a perspectiva sociocultural, com ferramentas teóricas relacionadas às instituições totais descritas por Erving Goffman. Resultados: A existência de vínculos externos à instituição e as rotinas eram motivadores de conflitos na Instituição de Longa Permanência para Idosos. O descontentamento pela inexistência de vínculos externos se manifestou pela impossibilidade de sair com familiares, receber visitas, objetos, dinheiro, alimentos ou atenção. Já a padronização e coletivização das rotinas internas de atividades básicas geravam insatisfações e desafiavam a tolerância das idosas às normas. Tais situações agregavam ao ambiente institucional condições oportunas à ocorrência de conflitos interpessoais. Conclusão: Os conflitos ocorriam entre idosas e profissionais, e entre elas, a partir das insubordinações das idosas, alicerçadas na ideia de reafirmação de suas individualidades.

\section{DESCRITORES}

Conflito Psicológico; Idoso; Instituição de Longa Permanência para Idosos; Enfermagem Geriátrica; Antropologia Cultural.

\section{RESUMEN}

Objetivo: Describir la influencia de las rutinas institucionales en la ocurrencia de conflictos interpersonales entre ancianas institucionalizadas. Método: Estudio cualitativo, con enfoque etnográfico, realizado con 17 ancianas de un establecimiento de larga estadía. La inmersión en el campo se llevó a cabo entre agosto de 2017 y mayo de 2018. Los datos se produjeron a través de la observación participante y un cuaderno de campo y se analizaron desde una perspectiva sociocultural, con herramientas teóricas relacionadas con las instituciones totales descritas por Erving Goffman. Resultados: La existencia de vínculos externos a la institución y las rutinas fueron motivadores de conflictos en el Establecimiento de Larga Estadía para Adultos Mayores. El descontento por la inexistencia de vínculos externos se manifestó por la imposibilidad de salir con familiares, recibir visitas, objetos, dinero, comida o atención. La estandarización y colectivización de las rutinas internas de las actividades básicas, por otro lado, generaron descontento y desafió la tolerancia de las ancianas a las normas. Tales situaciones se sumaron al entorno institucional condiciones propicias para la ocurrencia de conflictos interpersonales. Conclusión: Se produjeron conflictos entre ancianas y profesionales, y entre ellas, por las insubordinaciones de las ancianas, a partir de la idea de reafirmar su individualidad.

\section{DESCRIPTORES}

Conflicto Psicológico, Anciano; Hogares para Ancianos; Enfermería Geriátrica; Antropología Cultural.

\section{REFERENCES}

1. Barbosa KTF, Fernandes MGM. Elderly vulnerability: concept development. Rev Bras Enferm. 2020;73(Suppl 3):e20190897. DOI: https:// doi.org/10.1590/0034-7167-2019-0897.

2. Melo NCV, Teixeira KMD, Barbosa TL, Montoya AJA, Silveira MB. Household arrangements of elderly persons in Brazil: analyses based on the national household survey sample (2009). Brazilian journal of geriatrics and gerontology. 2016;19(1):139-51. DOI: https://doi. org/10.1590/1809-9823.2016.15011. 
3. Camarano AA, Kanso S. As instituições de longa permanência para idosos no Brasil. Rev Bras Estud Popul. 2010;27(1):232-5. DOI: http:// dx.doi.org/10.1590/S0102-30982010000100014.

4. Lini EV, Portella MR, Doring M. Factors associated with the institutionalization of the elderly: a case-control study. Brazilian journal of geriatrics and gerontology. 2016;19(6):1004-14. DOI: http://dx.doi.org/10.1590/1981-22562016019.160043.

5. Goffman E. Manicômios, prisões e conventos. $8^{\mathrm{a}}$ ed. São Paulo: Perspectiva; 2015.

6. Oliveira JM, Rozendo CA. Long-stay institutions for the elderly: a place of care for those who have no choice? Rev Bras Enferm. 2014;67(5):773-9. DOI: https://doi.org/10.1590/0034-7167.2014670515.

7. Souza RCF, Inacio AN. Inside the shelter walls: understanding the institutionalization process of elderlies sheltered. Pesqui Prát Psicossociais [internet]. 2017 [cited 2020 June 20];12(1):209-23. Available from: http://pepsic.bvsalud.org/scielo.php?script=sci_arttext\&pid=S1809$89082017000100015 \& \operatorname{lng}=$ pt\&nrm=iso.

8. Robbins SP. Fundamentos do Comportamento Organizacional. São Paulo: Pearson Prentice Hall; 2009.

9. Bao Y, Zhu F, Hu Y, Cui N. The Research of Interpersonal Conflict and Solution Strategies. Psychology. 2016;7(4):541-5. DOI: http:// dx.doi.org/10.4236/psych.2016.74055.

10. Bruinsma JL, Beuter M, Leite MT, Hildebrandt LM, Venturini L, Nishijima RB. Conflicts among institutionalized elderly women: difficulties experienced by nursing professionals. Esc. Anna Nery [Internet]. 2017 [citado 20 Mar 2020];21(1):e20170020. Available from: https:// www.scielo.br/j/ean/a/jFnpFrPNM4ZSwvnT7xg5MjC/abstract/?lang=en.

11. Fonseca C. Quando cada caso NÃO é um caso: pesquisa etnográfica e educação. Rev Bras de Educação. 1999;10:58-78.

12. Brasil. Ministério da Saúde. Resolução n. 466, de 12 de dezembro de 2012 [Internet]. Brasília; 2012 [cited 2020 Mar. 20]. Available from: http://bvsms.saude.gov.br/bvs/saudelegis/cns/2013/res0466_12_12_2012.html.

13. Zittoun T. Living Creatively, In and Through Institutions. Eur J Psychol. 2016;12(1):1-11. DOI: https://doi.org/10.5964/ejop.v12i1.1133.

14. Boelsma F, Baur VE, Woelders S, Abma TA. "Small" things matter: residents' involvement in practice improvements in long-term care facilities. J Aging Stud. 2014;31:45-53. DOI: https://doi.org/10.1016/j.jaging.2014.08.003.

15. Pirhonen J, Pietilä I. Perceived resident-facility fit and sense of control in assisted living. J Aging Stud. 2016;38:47-56. DOI: https://doi. org/10.1016/j.jaging.2016.04.006.

16. Pirhonen J, Tiilikainen E, Pietilä I. Ruptures of affiliation: social isolation in assisted living for older people. Ageing Soc. 2018;38(9): 1868-86. DOI: http://doi.org/10.1017/S0144686X17000289.

17. Barcelos BJ, Horta NC, Ferreira QN, Souza MCMR, Mattioli CDP, Marcelino KGS. Dimensions assigned to Long Term Care Facilities by managers and health professionals: interfaces and contradictions. Brazilian journal of geriatrics and gerontology. 2018;21(1):16-23. DOI: https://doi.org/10.1590/1981-22562018021.170082.

18. Zanello V, Henderson G, Silva LC. Nursing home as totalitarian instituition: gender and mental health [online]. 2017 [cited 2020 July 28];11(20):45-62. Available from: http://pepsic.bvsalud.org/scielo.php?script=sci_arttext\&pid=S1679-44272017000100004\&lng=pt\&nr $\mathrm{m}=$ iso.

19. Bittar CML, Moscardini AFM, Vanzela IBM, Souza VAP, Rocha JFG. Qualidade de vida e sua relação com a espiritualidade: um estudo com idosos em instituições de longa permanência. Revista Brasileira De Ciências Do Envelhecimento Humano. 2018;14(2):195-209. DOI: https://doi.org/10.5335/rbceh.v14i2.7020.

20. Vaismoradi M, Wang IL, Turunen H, Bondas T. Older people's experiences of care in nursing homes: a meta-synthesis. Int Nurs Rev. 2016;63(1):111-21. DOI: https://doi.org/10.1111/inr.12232. 